\title{
Escherichia coli in Chicken Carcasses in Southern Brazil: Absence of Shigatoxigenic (STEC) and Isolation of Atypical Enteropathogenic (aEPEC)
}

http://dx.doi.org/10.1590/1806-9061-2019-1093

\section{mAuthor(s)}

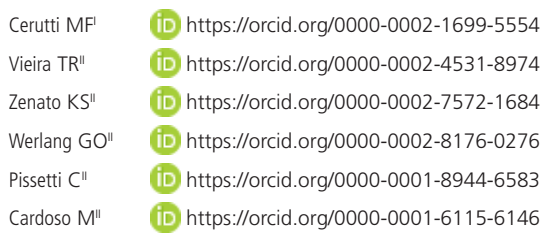

Programa de Pós-graduação em Ciências Veterinárias, Universidade Federal do Rio Grande do Sul, Porto Alegre, Rio Grande do Sul, Brasil

Departamento de Medicina Veterinária Preventiva, Universidade Federal do Rio Grande do Sul, Porto Alegre, RS, Brasil

\section{nail Address}

Corresponding author e-mail address Marisa Cardoso

Departamento de Medicina Veterinária Preventiva, Universidade Federal do Rio Grande do Sul, Porto Alegre, 91540000, RS, Brazil.

Phone: +55 5133086123

Email: mcardoso@ufrgs.br

\section{- Keywords}

Chicken meat; Enteropathogenic Escherichia coli; EPEC; Shigatoxigenic Escherichia coli; STEC.

\section{ABSTRACT}

The aim of this study was to investigate the presence of shiga toxin-producing Escherichia coli (STEC) and atypical enteropathogenic Escherichia coli (aEPEC) in frozen chicken carcasses sold at stores in southern Brazil. Typical E. coli colonies were enumerated in 246 chicken carcasses, and the presence of stx 1 , st $\times 2$, eae genes was investigated in their rinse liquid and in $E$. coli strains isolated from those carcasses. Strains of $E$. coli were also investigated for the presence of bfp gene. A

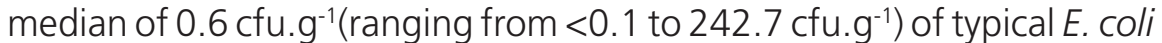
colonies was found in the carcasses. Shiga toxin-encoding genes (stx1 and stx2) were not detected, indicating that the chicken carcasses were negative for STEC. The intimin protein gene (eae) was detected in E.coli isolated from $4.88 \%$ of the carcasses; all tested strains were negative for the bfp gene and were classified as aEPEC. Twenty-two aEPEC strains were tested for resistance to ten antimicrobials and subjected to macrorestriction (PFGE). All the tested aEPEC strains were fully susceptible to cephalosporins, ciprofloxacin and colistin. Resistance to sulfonamide (65\%), ampicillin (55\%), tetracycline (50\%) and gentamicin $(45 \%)$ were the most frequent. The PFGE profile demonstrated a low level of similarity among the resistant strains, indicating that they were epidemiologically unrelated. The results indicate that aEPEC strains can contaminate chicken meat, and their association with strains implicated in human diarrhea needs to be further investigated.

\section{INTRODUCTION}

According to estimates of the World Health Organization, almost one in ten people falls ill and 420,000 die every year from eating contaminated food (WHO, 2015). Among the pathogens involved in foodborne disease, Shiga toxin-producing Escherichia coli (STEC)was responsible for more than 1 million illnesses, resulting in more than 100 deaths (WHO, 2015). Regarding STEC, the severity of the disease in humans contributes to its relevance, and infections have been associated with clinical illness ranging from mild non bloody diarrhea to hemolytic uremic syndrome, which often includes acute kidney failure. A high proportion of patients are hospitalized, some develop end-stage renal disease, and some die (Baker et al., 2016).

STEC comprises a large, highly diverse group of strains, which have the production of Shiga toxin (Stx) encoded by the genes stx 1 or stx2 in common. Moreover, pathogenesis includes common steps, including entry into the human gut, attachment to the intestinal epithelial cells usually via an intimin protein encoded by the eae gene, and the production of toxin. Stx and the ability to adhere to intestinal epithelial cells are regarded as major STEC virulence traits (FAOMHO, 2018). 
A range of foods should be considered when managing the risk of foodborne STEC infection. Overall, beef was identified as the most frequent food category attributed in outbreaks reported in the African, American, European and Eastern Mediterranean regions. Although chicken does not figure among the most frequent category involved in outbreaks, it was estimated that $0.30 \%$ (C195\% 0.290.33) of outbreaks in the Americas is attributed to chicken meat (FAOMHO, 2018). In Brazil, STEC was reported to be present in vacuum-packaged fresh beef samples collected from retailers (Castro et al., 2019), while in other types of meats STEC has only scarcely been investigated.

The atypical enteropathogenic E. coli (aEPEC) is also involved in human gastroenteritis and has been reported as one of the most prevalent causes of diarrhea affecting children and immunocompromised patients in Brazil (Dias et al., 2016). Some strains of this pathotype were found colonizing the gut of animals, including poultry (Alonso et al., 2016). The role of meat products as vehicles of aEPEC has been suggested, but its importance as a foodborne pathogen is not yet clear. Moreover, aEPEC strains isolated from animal and food were identified carrying resistance genes against multiple antimicrobial classes, such as aminoglycosides, tetracycline and $\beta$-lactams (Comery et al., 2013). In China, multidrug resistance was detected in $47.9 \%$ of aEPEC strains isolated from human patients and animals; however, strains originated from diarrheal patients showed a significantly higher frequency of MDR strains (Xu et al., 2018). Thus, more information about the emergence and spread of aEPEC resistant to antimicrobials among animal and food is still needed.

Chicken is the most consumed meat by the Brazilian population; moreover, this country is one of the largest broiler meat producers and exporters (ABPA, 2018). In this scenario of scale production and high consumption, the assessment of hazards in products available to consumers is relevant for public health. Since there are still few studies in Brazil investigating STEC in meat products and, to the best of our knowledge, no report on aEPEC in chicken meat, the aim of this study was to assess the presence of STEC and aEPEC in frozen chicken carcasses sold in food stores.

\section{MATERIAL AND METHODS}

\section{Study design}

The sample size was calculated considering an expected STEC prevalence of $1.5 \%$ (Alonso et al., 2012), assuming a 5\% relative error and a 95\% confidence interval. In this context, it was determined that a minimum of 224 samples were needed to ensure the detection of at least one STEC-positive carcass. To ensure representativeness, samples were collected at eight sales outlets in a medium-sized city (approximately 50,000 inhabitants) of the state of Santa Catarina. Each outlet was visited 10 times with a 7 to 15-day interval to obtain samples of different production batches. At each sampling event, one unit of product was collected per category and commercial brand available for sale. Only products packaged at the slaughterhouse were sampled to avoid any risk of cross contamination from handling at the retail stores. A total of 246 samples were collected, and they were distributed among the following categories: whole chicken $(n=139,57 \%)$; breeder $(n=39,16 \%)$; griller $(n=37,15 \%)$; marinade chicken $(n=26,11 \%)$; and backyard chicken $(n=5 ; 2 \%)$. The chicken samples were distributed among 13 different commercial brands. From these, 227 (92.3\%) originated from 16 slaughterhouses under the Federal Inspection Service located in seven Brazilian states. The remaining 19 samples $(7.7 \%)$ came from a slaughterhouse under the State Inspection Service located in Santa Catarina. The collected samples belonged to 83 different slaughter batches processed between February 2017 and February 2018.

\section{Sample processing}

After defrosting, the carcasses were individually transferred to sterile plastic bags, weighed and rinsed with $400 \mathrm{~mL}$ of $1 \%$ buffered peptone water (BPW, Merck Millipore, Darmstadt, Germany), according to ISO 17604 (amendment 1:2009) and ISO/TS 13136:2012 (E).The rinse liquid from each carcass was drained into a sterile container and was considered the zero-hour $(\mathrm{HO})$ sample.

To enumerate generic $E$. coli, aliquots of $1 \mathrm{~mL}$ from $\mathrm{HO}$ were plated on Chromocult $₫$ Coliform agar (Merck Millipore, Darmstadt, Germany) and incubated at $36^{\circ} \mathrm{C}$ $\left( \pm 1^{\circ} \mathrm{C}\right)$ for 48 hours. The violet blue colonies typical of $E$. coli were counted. The number of $E$. coli per gram of carcass was calculated by dividing the number of typical colonies by the carcass weight divided by 400 .

\section{Detection of stx1, stx2 and eae genes in the carcass rinsing liquid}

The detection of STEC on carcasses followed the methodology described in ISO/TS 13136:2012 (E). For this, an aliquot of $1 \mathrm{~mL}$ of $\mathrm{HO}$ was transferred to $9 \mathrm{~mL}$ of BPW $1 \%$, followed by incubation for $24 \mathrm{~h}$ at $36^{\circ} \mathrm{C}( \pm$ $\left.1^{\circ} \mathrm{C}\right)$, resulting in the day one sample $(\mathrm{H} 1)$. Total DNA 
extraction from $1 \mathrm{~mL}$ aliquots of $\mathrm{H} 1$ was performed with the PureLink $®$ Genomic DNA Kit (Invitrogen, Carlsbad, California, USA) according to the manufacturer's instructions. After extraction, the DNA concentration was verified in the Quantus ${ }^{\mathrm{TM}}$ fluorometer quantifier (Promega, Madison, Wisconsin, USA), and the total DNA concentration was standardized between 10 and $25 \mathrm{ng} / \mu \mathrm{L}$. The detection of st 1 , st $x 2$ and eae genes was performed by multiplex-PCR as previously described (Souza et al., 2013) using the primers depicted in Table 1.Each reaction was established to a final volume of $25 \mu \mathrm{L}$ and included $20 \mathrm{pmol} / \mu \mathrm{L}$ of each primer, 10x PCR Rxn Buffer (Invitrogen), $50 \mathrm{mM} \mathrm{MgCl}, 10 \mathrm{mM}$ dNTP's mix, 5 UTaq Polymerase (Invitrogen, Carlsbad, (alifornia, USA) and $2.5 \mu \mathrm{L}$ DNA. Gene amplification was performed on a Veriti® 96-Well thermal cycler (Applied Biosystems, Foster City, California, USA) under the following conditions: $1 \mathrm{~min}$ at $95^{\circ} \mathrm{C}$; followed by 35 cycles of $50 \sec 95^{\circ} \mathrm{C}, 30 \sec 62^{\circ} \mathrm{C}$ and $30 \sec 72^{\circ} \mathrm{C}$; and $10 \mathrm{~min}$ at $72^{\circ} \mathrm{C}$. The amplicons were submitted to $2 \%$ agarose gel electrophoresis with Blue Green loading dye (LGC Biotecnologia, Cotia, São Paulo, Brazil). The samples were visualized on a transilluminator, and the fragments were compared to a 100 bp GelPilot ${ }^{\circledR}$ DNA molecular weight marker (Qiagen, Hilden, Germany). For all reactions, sterile ultrapure water was used as the negative control, and the E. coli strain CDC2010C-3114 O11:H8 was used as a positive control.

\section{Detection of virulence genes in $E$. coli isolates}

In parallel to the detection of genes by $P C R$, aliquots of the $\mathrm{H} 1$ broth after incubation for $24 \mathrm{~h}$ at $36^{\circ} \mathrm{C}$ $\left( \pm 1^{\circ} \mathrm{C}\right)$ were transferred to $\mathrm{CHROM}^{\circ} \mathrm{Crar}^{\mathrm{TM}}$ (Becton Dickinson, Heidelberg, Germany) for the isolation of E. coli. Typical colonies originating from $\mathrm{H} 1$ broth that were positive for at least one of the tested genes by PCR (stx 1, stx2 and eae) were confirmed as positive for the aforementioned genes by the multiplex-PCR protocol described in the section 2.3. For this, $50 \mathrm{E}$. coli colonies from each plate were individually suspended in $90 \mu \mathrm{L}$ of sterile $0.9 \% \mathrm{NaCl}$ solution, and DNA was extracted by boiling (Ahmed \& Dablool, 2017). From each DNA extraction, $1 \mu \mathrm{L}$ was collected and pooled into five DNA pools (representing ten colonies/pool). Moreover, the same procedure was conducted for typical $E$. coli colonies isolated from $\mathrm{HO}$ corresponding to the same positive carcass samples. E. coli isolates from all pools that were positive for at least one virulence gene (stx 1 , stx2 and eae) were tested individually by multiplexPCR (as described in 2.3).

E. coli strains positive for the eae gene but negative for the stx gene were further investigated for the presence of the bfp gene, which codifies for the bundleforming pilus (Hu \& Torres, 2016). Each reaction was established in a final volume of $20 \mu \mathrm{L}$ and included 10 $\mu \mathrm{L}$ of GoTaq ${ }^{\circledR}$ Green Master Mix (Promega, Madison, Wisconsin, USA), $7 \mu \mathrm{L}$ of sterile ultrapure water, 0.5 $\mu \mathrm{L}$ of each primer (20 pmol/ $\mu \mathrm{L})$ (Table 1) and $2.0 \mu \mathrm{L}$ of DNA (10 ng/ $\mu \mathrm{L})$. Gene amplification was performed on a Veriti ${ }^{\mathrm{TM}}$ 96-Well thermal cycler (Applied Biosystems, Foster City, California, USA) under the following conditions: $1 \mathrm{~min}$ at $95^{\circ} \mathrm{C}$; followed by 29 cycles of $1 \mathrm{~min}$ at $94{ }^{\circ} \mathrm{C}, 1 \mathrm{~min}$ at $60^{\circ} \mathrm{C}$ and $1 \mathrm{~min}$ at $72{ }^{\circ} \mathrm{C}$; and $5 \mathrm{~min}$ at $72^{\circ} \mathrm{C}$. The amplicons were visualized as described above.

The strain E. coli ATCC 25922 was used as a negative control; the strains E. coli CDC2010C-3114 O11:H8 and E. coli E2348/69 were used as positive controls for the amplification of the genes stx and eae or the gene $b f p$, respectively.

All typical $E$. coli isolates that had at least one virulence gene detected were confirmed by routine biochemical tests as previously described (Markey et al., 2013).

\section{Antimicrobial resistance (AMR) testing}

An antimicrobial test against nine antimicrobials by the disk-diffusion method was performed and interpreted according to Matuschek et al. (2014) and EUCAST (2019). The following Oxoid ${ }^{T M}$ antimicrobial susceptibility disks (Thermo Fisher Scientific, Waltham,

Table 1 - Primers used for screening genes encoding Shiga toxin (stx), intimin protein (eae) and bundle-forming pili (bfp).

\begin{tabular}{lllcl}
\hline Gene & Primer & DNA sequence (5'-3') & Amplicon (bp) & Reference \\
\hline stx1 & stxA1 598 & AGT CGT ACG GGG ATG CAG ATA AAT & 417 & Bellin, Pulz, Matussek, Hempen \& Gunzer (2001) \\
& stxA1 1015 & CCG GAC ACA TAG AAG GAA ACT CAT & & \\
\hline stx2 & stx2F & GGC ACT GTC TGA AAC TGC CC & 255 & Bellin, Pulz, Matussek, Hempen \& Gunzer (2001) \\
& stx2R & TCG CCA GTT ATC TGA CAT TCT G & & \\
\hline eae & eaeF & ACT GGA CTT CTT ATT RCC GTT CTA TG & 189 & Hardegen, Messler, Henrich, Pfeffer, Würthner \& MacKenzie (2010) \\
& eaeR & CCT AAA CGG GTA TTA TCA CCA GA & & \\
\hline bfp & bfpF & AATGGTGCTTGCGCTTGCTGC & 326 & Gunzburg et al. (1995) \\
& bfrR & GCCGCTTATCCAACCTGGTA & & \\
\hline
\end{tabular}


Massachusetts, USA) were tested: ampicillin (10 $\mu \mathrm{g})$, cefotaxime $(30 \mu \mathrm{g})$, cefoxitin $(30 \mu \mathrm{g})$, ceftazidime (30 $\mu \mathrm{g})$, ciprofloxacin $(5 \mu \mathrm{g})$, chloramphenicol (30 $\mu \mathrm{g})$, gentamicin $(10 \mu \mathrm{g})$, sulfonamide $(300 \mu \mathrm{g})$ and tetracycline $(30 \mu \mathrm{g})$. Furthermore, the minimum inhibitory concentration (MIC) of colistin (SigmaAldrich, St. Louis, Missouri, USA) was also determined (EUCAST, 2019). E. coli ATCC® 25922 strains was used for quality control purposes.

\section{Macrorestriction profile}

Selected strains ( $n=20)$ were subjected to pulsedfield gel electrophoresis (PFGE) analysis following the procedures of Pulse-Net (https://www.cdc. gov/pulsenet/pathogens/pfge.html). Isolates were digested with Xbal (Promega), and electrophoresis was performed in a $1 \%$ agarose gel using $0.5 X$ Trisborate-EDTA buffer on a CHEF DR-II system (Bio-Rad Laboratories, Hercules, California, USA) at $6 \mathrm{~V} / \mathrm{cm}$ for $21 \mathrm{~h}$ at $14^{\circ} \mathrm{C}$ with an initial switch time of 6.76 $\mathrm{s}$ and a final switch time of $35.38 \mathrm{~s}$. The Salmonella BraenderupH9812 strain was used as a marker. After PFGE, the gel was stained with ethidium bromide (2 $\mu \mathrm{g} / \mathrm{mL}$ ), photographed under UV transillumination, and the image digitalization was processed by an L-Pix Touch System (Loccus Biotecnologia). PFGE-banding patterns were compared using the Gel-Compare II software package (Applied Maths, Kortrijk, Belgium). Similarities between profiles were calculated using the Dice coefficient with $1.7 \%$ tolerance. The patterns were clustered using the unweighted pair group method with arithmetic averages (UPGMA), and dendrograms were constructed.

\section{Statistical analyses}

The frequency of strains positive for the tested genes (stx 1, st $\times 2$, eae and bfp) and the antimicrobial resistance were analyzed by descriptive statistics. From the enumerations of typical colonies of Total Coliforms and $E$. coli on the carcasses, the median, minimum and maximum were calculated using $\mathrm{R}$ software ( $\mathrm{R}$ Core Team, 2018).

\section{RESULTS}

Among the 246 chicken samples evaluated for $E$. coli enumeration, no typical colonies were detected in $26.83 \%$. Among the positive samples, the typical

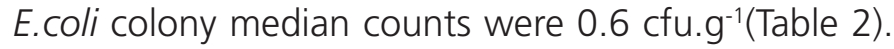
The food category breeder presented the highest $E$. coli median counts.

The detection of virulence genes in $\mathrm{H} 1$ broth from the 246 chicken samples was negative for the stx 1 and stx 2 genes. Thus, no STEC-positive chicken samples were detected. However, the $\mathrm{H} 1$ broth from 25 chicken samples (10.16\%) were positive for the eae gene; among those samples, the presence of virulence genes in pools of $E$. coli typical colonies obtained from $\mathrm{HO}$ and $\mathrm{H} 1$ was investigated.

Among the 159 ten-colony pools tested for the presence of $s t \times 1$ and $s t \times 2$ genes, all were negative. This result corroborated the absence of stx 1 and st $x 2$ amplifications, which has been performed directly from the $\mathrm{H} 1$ broth. Though, in $40(25.15 \%)$ of the 159 pools, the eae gene was detected, and 400 typical E. coli colonies obtained from these pools were individually tested for eae. Among them, 149 (37.25\%) were eae+ and were phenotypically confirmed as E. coli. All the149 confirmed $E$. coli eae+ strains were negative for the $b f p$ gene and were thus identified as atypical enteropathogenic $E$. coli (aEPEC) strains. Therefore, among the 246 investigated chicken carcass samples, in $12(4.88 \%)$ at least one aEPEC strain was detected. Positive samples belonged to whole chicken ( $n=9 / 139$; $6.47 \%$ ) and griller ( $n=3 / 37 ; 8.10 \%$ ) categories.

Twenty two aEPEC strains from chicken were tested for AMR. Two strains were susceptible to all tested antimicrobials, while twenty strains were susceptible to ceftazidime, cefoxitin, ciprofloxacin and colistin. Moreover, resistance to sulfonamide (65\%), ampicillin (55\%), tetracycline (50\%), gentamicin (45\%),

Table 2 - Enumeration of Escherichia coli in chicken samples collected at the retail level.

\begin{tabular}{|c|c|c|c|c|c|}
\hline \multirow[t]{2}{*}{ Food category } & \multirow[t]{2}{*}{ Number of samples } & \multirow[t]{2}{*}{ Not detected (\%) } & \multicolumn{3}{|c|}{ Positive } \\
\hline & & & $(\%)$ & Median $\left(\mathrm{cfu} . \mathrm{g}^{-1}\right)$ & Maximum (cfu.g $\left.g^{-1}\right)$ \\
\hline Whole chicken & 139 & 19.43 & 80.57 & 0.8 & 36.8 \\
\hline Breeder & 39 & 7.70 & 92.30 & 3.3 & 242.7 \\
\hline Griller & 37 & 56.76 & 43.24 & 0.1 & 17.3 \\
\hline Marinade chicken & 26 & 46.16 & 53.84 & 0.1 & 2.3 \\
\hline Backyard chicken & 5 & 60.0 & 40.0 & 0.1 & 0.8 \\
\hline Total & 246 & 26.83 & 73.17 & 0.6 & 242.7 \\
\hline
\end{tabular}

$\mathrm{cfu}=$ colony forming unit. 
chloramphenicol (20\%) and cefotaxime (5\%) was found. Half of the strains were resistant to three or more antimicrobial classes and were considered multidrug resistant (MDR) strains.

The macrorestriction of the strains subjected to the AMR test (Figure 1) demonstrated $100 \%$ similarity only between $E$. coli strains isolated from $\mathrm{HO}$ and $\mathrm{H} 1$ from

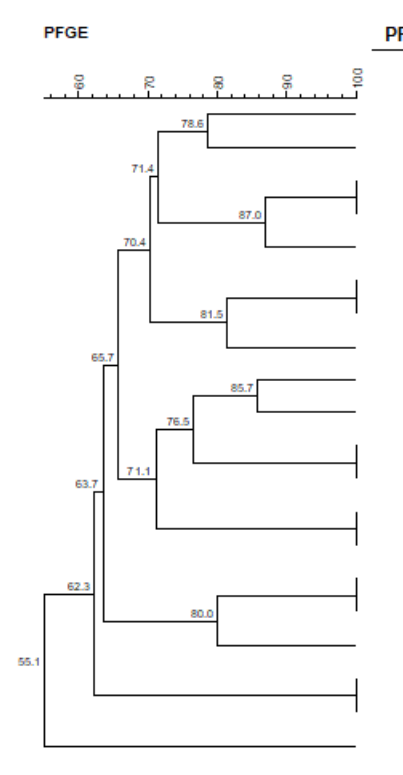

$$
\text { PFGE }
$$

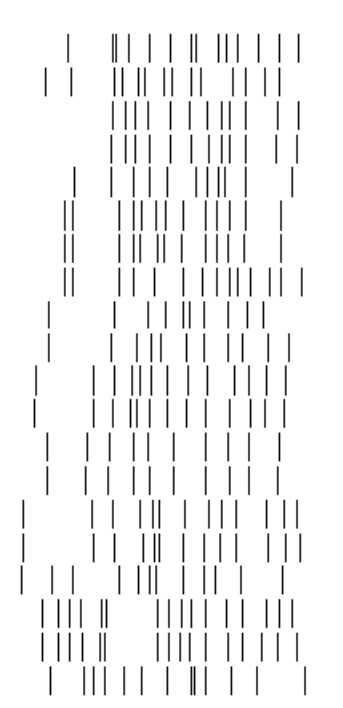

a same chicken carcass sample. All of these strains except one (\#107) displayed a common AMR profile, indicating that they might be the same strains isolated before and after the incubation of the rinse solution. The remaining strains presented similarities lower than $90 \%$ and were considered unrelated.

\section{DISCUSSION}

In the present study, shiga toxin-producing $E$. coli was not detected in frozen chicken carcasses originated from different slaughterhouses and sampled at retail points in a medium-sized city in Brazil. Cattle and sheep are considered to be the major reservoir of STEC, which can result in the contamination of meat and milk products (FAOMHO, 2018). In Brazil, STEC was isolated from bovine carcasses at slaughter (Loiko et al., 2016) and was later reported in $4.67 \%$ of vacuumpackaged fresh beef samples collected at retail stores (Castro et al., 2019). Other reported sources of STEC include water samples (3.8\% positive) collected from lettuce farming systems (Ceuppens et al., 2014) and fecal samples (1.27\% positive) of farmed Nile tilapia or wild fish (Cardozo et al., 2018). In both cases, environmental contamination with livestock manure was suggested as the possible origin.

In poultry, the presence of STEC has been reported in cloacal swabs taken from broilers in Argentinian farms, giblets and chicken meat in several countries (Lukásová et al., 2004; Chinen et al., 2009; Alonso et al., 2012; Bagheri et al., 2014; Bai et al., 2015). The frequency of STEC isolation from chicken meat in those studies was highly variable, ranging from $1.96 \%$

$\begin{array}{llllll}\text { stx1 } & \text { stx2 } & \text { eae } & \text { bpf } & \text { Phenotypic resistance profile } & \text { MIC colistin } \\ \text { negative } & \text { negative } & \text { positive } & \text { negative } & \text { Sul } & 1 \\ \text { negative } & \text { negative } & \text { positive } & \text { negative } & \text { AmpCloGenSulTet } & 1 \\ \text { negative } & \text { negative } & \text { positive } & \text { negative } & \text { AmpGenSulTet } & 1 \\ \text { negative } & \text { negative } & \text { positive } & \text { negative } & \text { AmpGenSulTet } & 1 \\ \text { negative } & \text { negative } & \text { positive } & \text { negative } & \text { SulTet } & 1 \\ \text { negative } & \text { negative } & \text { positive } & \text { negative } & \text { Amp } & 1 \\ \text { negative } & \text { negative } & \text { positive } & \text { negative } & \text { Amp } & 1 \\ \text { negative } & \text { negative } & \text { positive } & \text { negative } & \text { susceptible to all antimicrobials } & 1 \\ \text { negative } & \text { negative } & \text { positive } & \text { negative } & \text { GenSurTet } & 1 \\ \text { negative } & \text { negative } & \text { positive } & \text { negative } & \text { AmpGenSul } & 1 \\ \text { negative } & \text { negative } & \text { positive } & \text { negative } & \text { GenSul } & 1 \\ \text { negative } & \text { negative } & \text { positive } & \text { negative } & \text { GenSul } & 1 \\ \text { negative } & \text { negative } & \text { positive } & \text { negative } & \text { AmpCloSulTet } & 1 \\ \text { negative } & \text { negative } & \text { positive } & \text { negative } & \text { AmpCloSulT et } & 1 \\ \text { negative } & \text { negative } & \text { positive } & \text { negative } & \text { SulTet } & 1 \\ \text { negative } & \text { negative } & \text { positive } & \text { negative } & \text { AmpCloCtxSul } & 1 \\ \text { negative } & \text { negative } & \text { positive } & \text { negative } & \text { susceptible to all antimicrobials } & 1 \\ \text { negative } & \text { negative } & \text { positive } & \text { negative } & \text { AmpGenSulTet } & 1 \\ \text { negative } & \text { negative } & \text { positive } & \text { negative } & \text { AmpGenSulTet } & 2 \\ \text { negative } & \text { negative } & \text { positive } & \text { negative } & \text { Gen } & 1\end{array}$

(Bagheri et al., 2014) to 8.0\% (Chinen et al., 2009). The high frequencies reported in ground chicken and carcasses in studies conducted in Argentina (Chinen et al., 2009; Alonso et al., 2012) were attributed to hygiene failures in the production chain and processing and cross-contamination with beef at the retail level. Of the few studies conducted in Brazil in which STEC was investigated in chicken meat, no positive samples were detected in raw chicken legs and chicken cuts sampled at the retail level (Alvares, 2011; Ristori et al., 2017). To the best of our knowledge, chicken carcasses have not yet been investigated; thus, we conducted a sampling with a detection power of $1.5 \%$ prevalence and performed a protocol that allowed the screening of STEC virulence genes after an enrichment step. Since all samples were negative, we can infer that STEC is absent in frozen chicken carcasses or that its prevalence is very low.

Screening detected the eae gene in chicken carcass rinse fluid samples, indicating that enteropathogenic E. coli (EPEC) could be present. EPEC pathogenesis is related to the ability to produce attaching and effacing lesions on the intestinal epithelium (eae + gene) without shiga toxin production (Trabulsi et al., 2002). EPEC strains are further divided into typical (tEPEC) and atypical (aEPEC) strains by bundle-forming pilus (BFP) 
presence in tEPEC or absence in aEPEC (Hu \& Torres, 2016). Therefore, typical $E$. coli colonies originated from rinse fluid before and after the enrichment step were investigated for eae and bfp genes, and 12 (4.88\%) of the chicken carcass samples were confirmed as aEPEC positive. Animals and humans are reservoir of aEPEC, whereas tEPEC generally is carried in the guts of humans (Hernandes et al., 2009); however, there are reports of tEPEC in captive wild birds in Brazil (Sanches et al., 2017). While tEPEC strains are recognized as a cause of severe diarrhea in children (Trabulsi et al., 2002), the role of aEPEC as a human disease pathogen is less clear (Hernandes et al., 2009). However, studies have strongly associated aEPEC with acute or persistent diarrhea in children (Gomes et al., 2016). Although there is no confirmation of direct transmission from animals to humans, it has been suggested that some aEPEC strains may have zoonotic potential (Hu \& Torres, 2016). Moreover, animal stools carrying aEPEC may contribute to the dissemination of these strains into the environment, and raw meat contaminated with the intestinal content of reservoirs may be a possible transmission vehicle of aEPEC in human infections (Alonso et al., 2016; Gomes et al., 2016; Xu et al., 2016). However, the contribution of food as a vehicle of aEPEC in human disease is still unclear.

Atypical EPEC was detected in poultry cloacal samples (Alonso et al., 2011; Bagheri et al., 2014), indicating that chicken is a reservoir for these bacteria. In Argentina, aEPEC was detected in 3.9\% of chicken carcasses sampled in retail shops (Alonso et al., 2012), which is similar to the frequency reported in our study. The authors suggested that contamination during the evisceration process and the difficulty of removing bacteria with washing may cause the contamination of chicken carcasses, particularly the internal surface (Alonso et al., 2011; Alonso et al., 2012).In our study, we investigated the fluid that resulted from washing internal and external surfaces of the chicken carcasses, and the median value of $E$. coli was $0.6 \mathrm{cfu}^{-\mathrm{g}^{-1}}$ (ranging from $<0.1$ to $242.7 \mathrm{cfu}^{-\mathrm{g}^{-1}}$. The low counts of generic E.coli indicate a low level of fecal contamination, possibly related to a suitable process of evisceration and efficient hygienic measures taken at slaughter.

Antimicrobial resistance in potential zoonotic pathogens has been a growing worldwide concern (WHO, 2017). Although human diarrheagenic E. coli infections are usually self-limiting, persistent diarrhea caused by aEPEC might require treatment with antimicrobial dugs (Dias et al., 2016). Therefore, aEPEC strains isolated from each positive chicken carcass sample were tested for AMR. The results demonstrated the absence of resistant strains to antimicrobials classified as highest priority critically important for human medicine (WHO, 2017), such as ceftazidime, cefoxitin, ciprofloxacin and colistin. On the other hand, AMR frequency was higher for ampicillin and gentamicin than previously reported in aEPEC isolated from humans in Brazil (Dias et al., 2016). The resistance frequency to all tested antimicrobials, however, was lower than those found in generic E.coli isolated from poultry production systems in Argentina (Dominguez et al., 2018), China (Yassin et al., 2017) and Brazil (Stella et al., 2016). The aEPEC strains subjected to AMR testing showed low similarity on PFGE, indicating that there was no epidemiological relationship among the resistant or MDR strains.

This is the first report of aEPEC detection in chicken meat in Brazil, and the association of these strains with those implicated in human diarrhea needs to be further investigated. In the meantime, consumers should be encouraged to observe good hygiene when handling chicken meat and cooking it thoroughly to avoid the transmission of foodborne pathogens.

\section{ACKNOWLEDGMENT}

The authors would like to thank Dr. Roxane M. F. Piazza (Instituto Butantan) for supplying the E. coli strain E2348/69. This study was carried out with the support of the Coordination of Improvement of Higher Education Personnel - Brazil (CAPES) - Financing Code 001 (PNPD scholarship for C. Pissetti and PhD scholarships for T.R. Vieira and G.O. Werlang). K.S. Zenato received an undergraduate scholarship (IC Program) from CNPq.

\section{REFERENCES}

Ahmed OB, Dablool AS. Quality improvement of DNA extracted by boiling method in gram negative bacteria. International Journal of Bioassays 2017;6.04:5347-5349.

Associação Brasileira de Proteína Animal. Relatório anual 2018. 2018 Available from: http://abpa-br.com.br/storage/files/relatorio-anual345 2018.pdf.

Alonso MZ, Lucchesi PMA, Rodríguez EM, Parma $A E$, Padola NL. Enteropathogenic (EPEC) and Shigatoxigenic Escherichia coli (STEC) in broiler chickens and derived products at different retail stores. Food Control 2012;23:351-355.

Alonso MZ, Padola NL, Parma AE, Lucchesi PMA. Enteropathogenic Escherichia coli contamination at different stages of the chicken slaughtering process. Poultry Science 2011;90:2638-2641.

Alonso MZ, Sanz ME, Irino K, Krüger A, Lucchesi PMA, Padola NL. Isolation of atypical enteropathogenic Escherichia coli from chicken and chickenderived products. British Poultry Science 2016;57:161-164. 
Alvares PP. Ocorrência e caracterização de Escherichia coli produtora de toxina de Shiga na linha de abate de bovinos para exportação e em cortes refrigerados de bovinos e aves comercializados na região da Grande São Paulo [dissertation]. São Paulo (SP): Universidade de São Paulo; 2011.

Bagheri M, Ghanbarpour R, Alizade H. Shigatoxin and beta-lactamases genes in Escherichia coli phylotypes isolated from carcasses of broiler chickens slaughtered in Iran. International Journal of Food Microbiology 2014;177:16-20

Bai $X$, Wang $H$, Xin $Y$, Wei $R$, Tang $X$, Zhao A, et al. Prevalence and characteristics of Shiga toxin-producing Escherichia coli isolated from retail raw meats in China. International Journal of Food Microbiology 2015;200:31-38

Baker CA, Rubinelli PM, Park SH, Carbonero F, Ricke SC. Shiga toxinproducing Escherichia coli in food: Incidence, ecology, and detection strategies. Food Control 2016;59:407-419.

Cardozo MV, Borges CA, Beraldo LG, Maluta RP, Pollo AS, Borzi MM, et al. Shigatoxigenic and atypical enteropathogenic Escherichia coli in fish for human consumption. Brazilian Journal of Microbiology 2018;49:936941.

Castro VS, Teixeira LAC, Rodrigues DP, dos Santos LF, Conte-Junior CA, Figueiredo EES. Occurrence and antimicrobial resistance of $\mathrm{E}$. coli non-0157 isolated from beef in Mato Grosso, Brazil. Tropical Animal Health and Production 2019;51(5): 1117-1123.

Ceuppens S, Hessel CT, Quadros Rodrigues R, Bartz S, Tondo EC, Uyttendaele M. Microbiological quality and safety assessment of lettuce production in Brazil. International Journal of Food Microbiology 2014;181:67-76.

Chinen I, Epszteyn S, Melamed CL, Aguerre L, Martínez Espinosa E, Motter MM, et al. Shiga toxin-producing Escherichia coli 0157 in beef and chicken burgers, and chicken carcasses in Buenos Aires, Argentina. International Journal of Food Microbiology 2009;132:167-171.

Comrey R, Thanabalasuriar A, Garneau P, Portt A, Boerlin P, Reid-Smith R, et al. Identification of potentially diarrheagenic atypical enteropathogenic Escherichia coli strains present in canadian food animals at slaughter and in retail meats. Applied and Environmental Microbiology 2013;793892-3896.

Dias RCB, dos Santos BC, dos Santos LF, Vieira MA, Yamatogi RS, Mondelli $A L$, et al. Diarrheagenic Escherichia coli pathotypes investigation revealed atypical enteropathogenic E. coli as putative emerging diarrheal agents in children living in Botucatu, São Paulo State, Brazil. APMIS 2016;124:299-308

Dominguez JE, Redondo LM, Figueroa Espinosa RA, Cejas D, Gutkind GO, Chacana PA, et al. Simultaneous carriage of mcr-1 and other antimicrobial resistance determinants in Escherichia coli from poultry. Frontiers in Microbiology 2018;9:1679.

EUCAST - European Food Safety Authority. The European Union summary report on trends and sources of zoonoses, zoonotic agents and foodborne outbreaks in 2016. EFSA Journal 2017;15:5077.

EUCAST - European Committee on Antimicrobial Susceptibility Testing. Breakpoint tables for interpretation of MICs and zone diameters. V. 9.0. 2019. Available from: http://www.eucast.org/fileadmin/src/media/ PDFs/EUCAST_files/Breakpoint_tables/v_9.0_Breakpoint_Tables.pdf

FAOMHO - Food and Agriculture Organization of the United Nations/ World Health Organization. Shiga toxin-producing Escherichia coli (STEC) and food: attribution, characterization, and monitoring. 2018. Available from: http://www.fao.org/3/ca0032en/CA0032EN.pdf

Gomes TAT, Yamamoto D, Vieira MAM, Hernandes RT. Atypical enteropathogenic Escherichia coli. In: Torres AG. Escherichia coli in the Americas. Cham: Springer;2016. p.77-98.
Hernandes RT, Elias WP, Vieira MAM, Gomes TAT. An overview of atypical enteropathogenic Escherichia coli. FEMS Microbiology Letters 2009:297:137-149.

$\mathrm{Hu}$ J, Torre AG. Enteropathogenic Escherichia coli: Foe or innocent bystander? Clinical Microbiology and Infection 2015;21:729-734.

Loiko MR, de Paula CMD, Langone ACJ, Rodrigues RQ, CibulskiS, Rodrigues $\mathrm{RO}$, et al. Genotypic and antimicrobial characterization of pathogenic bacteria at different stages of cattle slaughtering in southern Brazil. Meat Science 2016;116:193-200.

Lukášová J, Abraham B, Cupáková Š. Occurrence of Escherichia coli 0157 in raw material and food in Czech Republic. Journal of Veterinary Medicine Series B: Infectious Diseases and Veterinary Public Health 2004;51:77-81

Markey B, Leonard F, Archambault M, Cullinane A, Maguire D. Clinical veterinary microbiology. 3rd ed. London: Mosby Elsevier; 2013.

Matuschek E, Brown DFJ, Kahlmeter G. Development of the EUCAST disk diffusion antimicrobial susceptibility testing method and its implementation in routine microbiology laboratories. Clinical Microbiology and Infection 2014;20:0255-0266.

R Core Team. R: a language and environment for statistical computing. Vienna: R Foundation for Statistical Computing; 2018.

Ristori CA, Rowlands REG, Martins CG, Barbosa ML, dos Santos L, Jakabi $M$, et al. Assessment of consumer exposure to Salmonella spp., Campylobacter spp., and shiga toxin-producing Escherichia coli in meat products at retail in the city of Sao Paulo, Brazil. Foodborne Pathogens and Disease 2017;14:447-453.

Sanches LA, Gomes MS, Teixeira RHF, Cunha MPV, Oliveira MGX, Vieira MAM, et al. Captive wild birds as reservoirs of enteropathogenic E. coli (EPEC) and Shiga-toxin producing E. coli (STEC). Brazilian Journal of Microbiology 2017;48:760-763.

Souza TB, Lozer DM, Kitagawa SMS, Spano LC, Silva NP, Scaletsky ICA. Real-time multiplex PCR assay and melting curve analysis for identifying diarrheagenic Escherichia coli. Journal of Clinical Microbiology 2013;51:1031-1033.

Stella AE, Oliveira MC, Fontana VLDS, Maluta RP, Borges CA, Ávila FA. Characterization and antimicrobial resistance patterns of Escherichia coli isolated from feces of healthy broiler chickens. Arquivos Do Instituto Biológico 2016;83:e0392014.

Trabulsi LR, Keller R, Tardelli Gomes TA. Typical and atypical enteropathogenic Escherichia coli. Emerging Infectious Diseases 2002;8:508-513.

WHO - World Health Organization. WHO estimates of the global burden of foodborne diseases. 2015. Available from: https://www.who.int/ foodsafety/publications/foodborne_disease/fergreport/en/

WHO - World Health Organization. Critically important antimicrobials for human medicine. 5th ed. 2017. Available from: https://www.who.int foodsafety/publications/antimicrobials-fifth/en/

Xu Y, Bai X, Zhao A, Zhang W, Ba P, Liu K, et al. Genetic diversity of intimin gene of atypical enteropathogenic Escherichia coli isolated from human, animals and raw meats in China. PLoS One 2016;11:e0152571.

Xu Y, Sun H, Bai X, Fu, S, Fan R, Xiong Y. Occurrence of multidrug-resistant and ESBL-producing atypical enteropathogenic Escherichia coli in China. Gut Pathogens 2018;10:8

Yassin AK, Gong J, Kelly P, Lu G, Guardabassi L, Wei L, et al. Antimicrobial resistance in clinical Escherichia coli isolates from poultry and livestock, China. PLoS One 2017;12:e0185326. 
